\title{
RANKINGS TAX AFFAIRS OFFICE OF THE EAST OF TEHRAN WITH THE TAX CAPACITY APPROACH USING TOPSIS METHOD
}

\author{
Somayeh Movahedy \\ Department of Communication Science, Tehran Shargh Branch, Islamic Azad University, Tehran, Iran
}

\begin{abstract}
Taxation is the most important tool of the government's fiscal policy, which speeds up the process of economic growth, and constitutes one of the most major and most stable sources of income for governments. Comparison this source with other sources suggests that, whatever the contribution of taxes is more in provision of government expenditures, economic adverse effects are reduced, significantly. Accordingly, it is necessary to taxation problems, be analyzed by estimating the throughput and efficiency of the tax system, and practice, in order to overcome them, and to identify new ways of taxing, to reduce exist tax gap between tax revenues and tax capacity, by adopting the methods and measures. In the present study, as the regional study, is trying to rank Affairs tax Office of East of Tehran, by examining six factors influencing the actual capacity of tax, as amount of tax collecting, number of tax employees, etc, and testing their effectiveness with TOPSIS method, based on information from 2011, to evaluate the inter-organizational factors influence the capacity of the tax. In this study, researcher collected research data, without any kind of tampering, and with the help of interviews with tax experts, and visiting the tax affairs offices of East of the state. The results of the entropy technique, showed that the amount of collected taxes, with weight 0.2444 , has the most importance, and the ratio of the number of records, compared with number of employees, with the weight of 0.0412 , has the lowest importance among six identified indicators. Finally, it was determined that, among the tax Affairs Offices of East of Tehran, tax affairs office of Boomehen, with $\mathrm{C}_{\mathrm{A} 2}{ }^{*}=0.7099$, is the first, and tax affairs office of Pardis, with the $\mathrm{C}_{\mathrm{A} 1}{ }^{*}$ $=0.2493$, is on the last place.
\end{abstract}

Keywords: Tax affairs office, tax actual capacity, weight indicators, entropy technique, TOPSIS Method

\section{INTRODUCTION}

Different economical systems define different definitions for the governments. The degree of governments' interference in affairs of some of the systems is low. In some of systems that is wonderful \& in some of them is the middle. But the most important point is that the government need remarkable financial sources for the progress of given affairs, especially in defending $\&$ representing public services.

Economical needs of the government can be provided from different sources like taxes, selling wealth or primary mineral material effectiveness of the taxes system \& determining taxation prices for different people of a society is one of the concerns of the governments \& economical systems in the world, in a way which can cause the highest income by gaining the taxation capacity. taxation capacities is one of those concepts which is focused less, despite its importance in short time \& ling time planning \& operational organizing $\&$ amendment methods.

In fact, the taxation capacity is the taxation volume that the society has the capability of affording it (or it can afford).

The taxation capacity also shows that how much a country or an area has tried in equipping taxation sources \& also shows that how much it can increase these sources. The share of added value of the different economical parts in impure production is one of the important factors of determining taxation volume in an area as a result; the taxation capacity become higher, with more literacy share rate is also one of the other determining factors of taxation capacities in a society which call it as taxation culture. 
The literacy \& understanding \& perception from taxes \& paying philosophy in a society can have a direct relationship with taxation capacity. Some other effective variables such as the number of taxation stuff, collected tax rate, the number of delivered declaration forms inflation, rules, \& etc, can also counted as other effective factors in taxation capacity.

General policy of the government in last year has been reliance decrease of the budget (specially the current budget) to the oil incomes 7 increasing the share of not oily incomes specially taxation incomes by improving $\&$ amendment of system $\&$ taxation system. because the taxation incomes have pretty less vacillations \& also because it's accompanied by governments more responding in front of people \& is considered as the cheapest source of financial providing of countries, so it can have a wide role \& function in wealth adjustment 7 income, improving social \& economical justice \& prevention from income inequality, corroboration, by its further distribution \& is accounted as one of the important \& powerful in performing governments policies in facing with economical crisis's. on the basis of that, in current research it's tried to deal with rating of the taxation affairs of the offices in east of Tehran, by using tapsis method in addition to considering effective inter-organizational factors on actual taxation capacity.

\section{STATING THE PROBLEM}

Any government needs financial equipments and sources for managing the society \& performing its plans in order to do desirably those duties which are given to them by people. Taxation, as the most important $\&$ healthiest income sources of governments, has been under attention \& consideration from the start of society forming of society $\&$ governments.

Nowadays economic experts in all countries know the taxation as the best source for providing government's prices. In some countries, such as Iran, because of availability to the replacing sources, do not pay attention to tax revenues. Such as oily incomes, they don't pay attention to these taxation incomes as needed (Azimi, 1992). But these countries also pay attention to its important \& fundamental role in budget structure $\&$ are searching for the quality of their taxation capacity increase. the importance of taxation incomes never hide from the eyes of policy makers in a way that, using the maximum taxation capacities, is being spoken as one of most important fundamental policy for decreasing the economical dependence of the country to oil incomes \& providing the current costs of government by long term taxation incomes. In the third economical, social \& cultural plan rule, article (59) permit's the government to create the taxation organization of the country as an governmental institute which is being controlled by the minister of financial \& property affairs, in order to increase the effectiveness of taxation system \& omit the present organizational obstacles \& also to increase the focus on all of the affairs which are related to the grasping taxation. according to article (2) of the law of the fourth progress Islamic republic of Iran plan, government is to completely provide the costs of government by taxation in comes \& other not oily incomes, until the end of this plan. In the plan of fifth progress (2011-2015), article (117) it's mentioned that, in order to completely stop the depending of the government's costs to the oil \& gas incomes in a way which, the ratio taxes to the Inner impure production, reach at least to 10 percent.

According to a 20 year old outlook of the country, the government must be able to provide its present costs mostly from taxation in comes \& decrease the dependence of this part to the oil incomes. taxes, in different countries of the countries constitutes a great part of general costs which government needs is provided by taxes, but in spite of governments much efforts, this number in Iran is not enough \& has a lot of difference with the prevalent numbers of the world. In addition, about 32 percent of the Inner impure production of some countries is provided from taxation incomes, while this number is very low in Iran. (Elias Naderan, 2005).

With attention to the represented explanation, this question is aroused that: what are the effective interorganizational factors on taxation capacity? 
According to the proposed description, this question is posed that, what inter-enterprise factors influence on the tax capacity? To answer this question, and also clarify the controversial issue, we decided to analyze the problems in taxation through the estimation of the power and efficiency of the tax system, and with adoption policies and measures act in order to overcome them, and to identify new ways to tax, to reduce the tax gap, between the current tax revenues and tax capacity. The goal of this study is consideration the tax capacity of tax administrations of east of Tehran, and the inter-organizational factors affecting on it, and also investigate the mechanism of tax collection, and rank the Tax Office in East of Tehran, according to the definition of the actual tax capacity, and by introduced 6 indicators, and using TOPSIS methods (which are classified as multi-criteria decision making model (MADM) ${ }^{1}$ ).

\section{LITERATURE}

The consideration of taxation capacity \& its effective factors have been among interesting research subjects in developing countries, for a few decades. Primary researches in this field is done by Chilia (1971) \& Chilia \& others (1975) in international box of money.

1] Chilia (1971) in the consideration of tax making progress of developing countries along the period of 1953-1986 by the use of sectional data has focused on the calculation of taxation capacity in 50 developing countries. In this effort which is known as a base for next works; he considers the capitation income variables, non exporting capitation income, the share of mine part production in Inner impure production $\&$ the ratio of the non mineral exportation to the inner impure production, as the effective factors on taxation capacity. the dependent variable has been the taxation ratio of the countries and four patterns with the least ordinary squral patterns (OLS) ${ }^{2}$ are done. the results show that the share of the mineral productions in inner impure production and the ratio of the exportation to the inner impure production, has been the most effective factors on taxation capacity in developing countries(Hanifi et al, 2014). the coefficient of the agricultural productions /share in inner impure production is negative and the other variables coefficient in models is in accordance with economical theories. Eventually the writer alarms that even if all the effective factors on taxation capacities have not been accounted by used variables. the comparison which is done according to taxation ratios is more accurate than the comparison according to current taxation ratios.

2] Chilia et al (1975) with the consideration of taxation ratios \& taxation effort in developing countries during the period of 1969-1397, considered the taxation capacity in 47 developing countries. The results showed that the capitation income the added value of mineral parts \& non mineral parts are the effective factors on taxation capacity in developing countries.

3] Alfirman (2003) has focused on the consideration of taxation capacities under the condition of non centrality in local governments of Indonesia. He has considered the taxation capacity of 26 Indonesian estates during 1996-1999. In this study the effective variables on taxation capacities include: literacy rate, the ratio of the shore of work power \& ratio all the exportation \& importation to the Inner impure production which have positive \& meaningful effects \& the share of the agricultural part from GDP which has a negative influence on taxation capacity.

4] Butel Hol (2010), in a research with the name" taxation effort \& determining factors under Sahara desert "shoes that the quality of institutes $\&$ the income of sources are the powerful determining factors of taxation ratio. So if the countries improve the quality of their institutes, the can gain more taxation incomes from the sources. In most of the studies, the capitation income (GDP capitation) plays the main role $\&$ the effect of the business freeing is confirmed. this research also measures the taxation effort of the areas \& shows that during (1990-2007) the countries under Sahara desert have acted lower than their potential taxation in other words they haven't had a desirable function.

${ }^{1}$. multiple Attribute Decision making

2 . Ordinery Least Square

Submit Date: 19.06.2016, Acceptance Date: 19.07.2016, DOI NO: 10.7456/1060AGSE/010

Copyright (C) The Turkish Online Journal of Design, Art and Communication 
5] Ghani (2011) in his study focuses on the intra-country analysis of the taxation function with a special emphasis on the taxation effort of Pakistan, with the use of 104 panel data of the country during the period (1996-2005). Usually freeing capitation GDP $^{1}$, suburban population, governing of the law \& the control of corruption are determined as the determining factors of the taxation ratio among countries.

\section{ABSTRACT BASEMENT OF RESEARCH}

Different definition is represented in relation with taxation capacity. Taxation capacity shows the power of society in paying taxes $\&$ in fact this is the taxation volume which society can potentially pay it. In other words, taxation capacity is the taxation amount which people can by.

In Mehregan \& Pejman's (2005) opinion the taxation capacity is the maximum taxes that with attention to the income distribution level, its combination \& the current laws in any country in a long term period are achievable.

Ghetmiri \& Eslamlooian (2008) tells that what is understood from taxation capacity is the taxation amount which a country potentially is capable of receiving it in any period.

The taxation capacity is the amount of the capacity which a society can afford it with attention to the taxation fundamentals \& this power depends on the incomes, consumes investments $\&$ also depends on the long term goals \& short term \& medium term planning (Manochehr Farhang; 1984- page 1274)

In fact the taxation fundamental is that taxes receiving bas. This base can be the income or added value, wealth or any other economical variable which is representative of citizens' ability in using public equipments that are presented by government.

Potential taxation capacity: there are different definitions for taxation capacity that in one of it's most complete ones, the potential taxation capacity is divided into two following parts (Abas Arab Mazar and Ayat Zayer, 2008)

1. The legal potential capacity (with dependence on the production and available taxation rules.

2. The economical potential capacity (with dependence on production and the rules of other countries)

The legal potential capacity of taxes is the amount of taxes which are gained in a country according to the rules.

The economical potential capacity of taxes in a country is defined as the potential ability of economy of that country in creating taxes, without paying attention to the taxation rules of that country with assuming the performances of the countries which are in a same group or they are same from economical aspect.

\section{Actual taxation capacity}

The actual taxation capacity includes all of the received taxation incomes (received taxations) in a country during a year (Manuchehr Farhang, 1984-page 1274). Or actual taxation capacity is amount of the taxes which are calculated with attention to the performance of the country during different years. (Musavi, Seyed yahya, 2008)

The taxation capacity of each region is related to the ability of the government in receiving taxes in addition to the affording rate among the people of a society.

_Effective factors on taxation capacity.

${ }^{1}$. Gross Domestic Product

Submit Date: 19.06.2016, Acceptance Date: 19.07.2016, DOI NO: 10.7456/1060AGSE/010

Copyright (C) The Turkish Online Journal of Design, Art and Communication 
The factors which influence on country, s taxation capacity are not same; they change with passage of time and with changes that happen in economy. With this concentration different ideas are given about effective factors on taxation capacity. generally, the effective factors on taxation capacity can be summerised as below with separating out-organizational and in-organizational factors (Yegane Musavi Jahromi and Ayat Zayer, 2008)

Effective factors on taxation capacity:

*1. Out-organization factors effective factors on individuals \& society's ability in paying taxes:

1. 1; structural factors; different capitation income of economy situation of income large taxation

1. 2; official factors: a perception toward the government sense of responsibility. Individual honesty taxation

*2. In-organization factors, effective factors on government's ability in collecting taxes:

2. 1; structural factors: the structural factors; the structure of taxation; bases \& costs

2. 2; official factors; official organization, the way of its performance \& its costs.

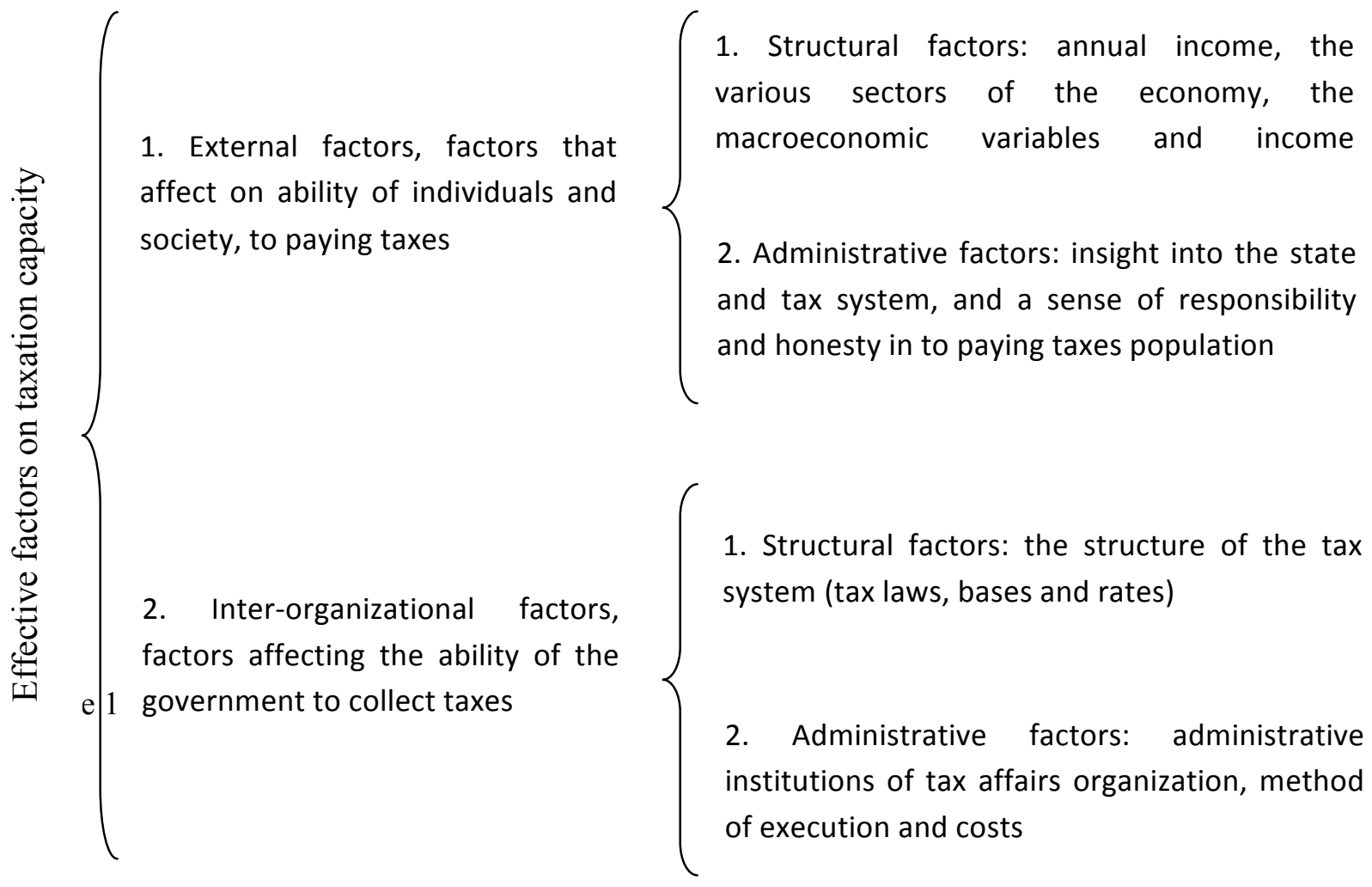

Factors affecting on ability of individuals and society, paying taxes, are determined by two, structural and voluntary factors. The most important structural factors, affecting the ability of people to pay taxes are per capita income, economic structure of society and the importance of different types of economic activities, and macroeconomic policy. Higher level of per capita income generally leads to higher levels of savings lower rates of illiteracy, a reasonable level of economic development, etc., in general, make the levy and 
collection of taxes, easy. Thus, income per capita, due to its effects on the ability to pay the tax, is seen as the most important factor to determining the tax capacity.

The combination of the income and the amount of importance and width of economical activities are among effective factors on individual's ability in paying taxes; for example, the importance of agricultural part and the level to which this part can be put in to business in comparison with the level of it's livelihood influences oil incomes negatively. On the other hand, industrial and mineral productions and servicing activities are causers of wide taxation bases. Basically one of the greatest governmental income sources in developing countries is the situation of taxes on objects as taxes on exportation and importation. The huge economical policies can influence on the taxation income by real value of exchange cost, the rate of importation limitations, level of public debt, level of benefit costs, inflation rate and with using other policies. These factors are important in determining taxation level in a specific time and the way it changes during the time. In lots of cases, the remarkable changes in taxation level can be changed directly or indirectly in such these policies.

The effective official factors on the ability of society's individuals in paying taxes include: taxation culture of the society, the kind of public view toward taxation system, sense of responsibility and honesty of people in paying taxes and also citizen's ideas toward the government. (which itself can be influenced by the quality of public services and way of paying taxation incomes) totally the development of taxation cultures in society is one of the effective factors in paying taxes, in a way that individuals know the payment of taxes as their duty and a right understanding from government's duties in gaining a percent of society's national production and using it in providing public needs.

The ability of governments to collect taxes, in addition to structural factors, depends on many other administrative factors. In many developing countries, the low level of tax revenues is due to the lack of complete and accurate implementation of tax laws, which it often is due to inappropriate administrative systems and procedures for the detection and collection of the tax.

_Inter-organizational effective factors on taxation capacity (actually)

According to the definition of taxation actual capacity, the effectiveness of the official system of recovery taxes and the taxation rules on the amount of tax taking of a country is effective, in this part of research we have focused on the recognition and introduction of determiner or effective factors on taxation capacity in the form of controlling factors on the ability of recovery taxes by government (interorganizational factors). This group of factors (inter-organizational) often depends on the present rules and the official structure of the recovery taxes system. the ability of the government can be assessed by different indicators. Some of these indicators include: the budget of taxation affairs, the number of employers of performing units, the number of taxation declaration forms which are delivered by taxation determiners.

In this research, with attention to the available static equipments, 6 indicators: Recovered taxes, the number of taxation employers, the number of delivered declaration forms The number of files which include taxes, the ratio of taxation files to the number of taxation employers and the number of sent files to the problem solving groups as the determiner of the ability of the taxation recovery from government are being focused:

\section{A: the recovered tax rate.}

The numbers which are related to the recovered taxes in any region is a symbol of taxation capacity of this area. In addition to that the recovered taxes in any area shows its economical ability and it can be accounted as criteria for measuring the ability of recovery of taxes from related taxation affairs office. (Positive indicator or income) 
B: the number of taxation employers

The recognition of income owners processes, the recognition and recovery of taxes in the country, because of their nature and taxation recovery operational systems are often done by reliance to the specialist human power.

So, providing the specialist man power for taxation offices and training them, increases the government's ability in recovering taxes. If with the increase in the number of taxation employers, the ratio of taxation determiners decreases, it causes each taxation employer to have more opportunity for checking and recovering taxes of each file. Generally, we can declare that there are direct connectors among other taxation employers, as an indicator of taxation recovery ability. (Positive indicator or income)

$\mathrm{C}$ : the number of taxation declarations:

The number of delivered declarations can also be considered from the aspects of ability and society's individuals' yen toward paying taxes and also from the aspect of the ability of receiving taxes by the governments.

D: the number of files which include taxes (non exempt)

The increase in the number of files which consists of taxation in a region is a symbol of industrial and economical activities which consists of taxation (because some of the activities, like agriculture are exempt from taxes), taxation capacity of taxation affairs offices, also will increase and there is a direct relationship between files which include taxes and taxation capacity. (Positive indicator or income)

By saying tax inclusive files, we mean non exempt files which consist of inclusive and non inclusive files.

E: the ratio of taxation files to the taxation employers.

If the ratio of the number of files (including all files, from inclusive and non inclusive and exempt files) to the taxation workers be lower, the taxation capacity will increase with attention to the fact that each taxation employer has more time for checking and recovering taxes for each file. This indicator has a negative relationship with the taxation capacity, in other words, if the ratio of taxation files to the taxation workers be low, the taxation capacity will increase (negative or cost indicator)

F: the number of sent files to the taxation problem solving groups.

It is possible that because of some reasons some differences will be made between the individuals' taxation tools and determined taxations by taxation affairs office, these differences in addition to the increase of disagreements, these people cause lengthen and procrastination in paying taxes, and governments' time are spent for solving those cases which eventually causes delay in taxation recovery and it will increase the recovery of costs. so if the number of sent files to the taxation problem solving groups would be lower, the taxation capacity will increase. so there is an opposite relationship among the number of sent files to the taxation problem solving groups and taxation capacity.

G: analysis of data

A; the discretional part of the research:

The determined indicators with attention to the collected data are considered in this part and the results are presented in the table on the basis of it's plenitude and percent:

- The recovered taxation $\left(\mathrm{x}_{1}\right)$ : 
Recovered taxation is a positive indicator $(+)$. the amount of recovered taxes of all of the sources includes taxation on company's incomes, jobs (A, B, C, line), heritage, automobile, tenement, (the income from renting properties and moving them) salary taxation, and also taxes on added value (includes taxes and imposition of added value + polluting imposition + taxes of moving automobile) which is represented in table number 1 by separating each taxation affairs office:

Table 1: Frequency distribution of tax affairs Office, according to the amount of collected tax in 2011

\begin{tabular}{|l|l|l}
\hline $\begin{array}{l}\text { Tax } \\
\text { Administration }\end{array}$ & The amount of collected tax $\left(\mathrm{X}_{1}\right)$ & Percent \\
\hline pardis & 10284779476 & 2.5 \\
\hline Boomehen & 118274963974 & 28.5 \\
\hline Roodehen & 40182141453 & 9.7 \\
\hline Damavand & 43534638735 & 10.5 \\
\hline Firoozkooh & 39095916185 & 9.5 \\
\hline $\begin{array}{l}\text { Value Added in } \\
\text { the east of } \\
\text { Tehran }\end{array}$ & 162721108000 & 39.3 \\
\hline total & 414093547823 & 100 \\
\hline
\end{tabular}

The number of taxation workers $\left(\mathrm{x}_{2}\right)$ : the number of taxation workers is a positive $(+)$ indicator. According to the results of the table number 2, the most plenitude is for Bumehen taxation affairs office.

Table 2: Frequency distribution of the Office of Tax Affairs of the study, based on the number of tax staff

\begin{tabular}{|l|l|l}
\hline $\begin{array}{l}\text { Tax } \\
\text { Administration }\end{array}$ & Number of Tax Employees $\left(\mathrm{X}_{2}\right)$ & Percent \\
\hline pardis & 10 & 7.6 \\
\hline Boomehen & 46 & 34.8 \\
\hline Roodehen & 23 & 17.4 \\
\hline Damavand & 22 & 16.7 \\
\hline Firoozkooh & 17 & 12.9 \\
\hline $\begin{array}{l}\text { Value Added in } \\
\text { the east of } \\
\text { Tehran }\end{array}$ & 14 & 10.6 \\
\hline total & 132 & 100 \\
\hline
\end{tabular}

The number of delivered declaration forms $\left(\mathrm{x}_{3}\right)$ :

The number of delivered declaration forms is a positive $(+)$ indicator

According to the results of the table number 3, the most plenitude is for Bumehen taxation affairs office and the least plenitude is for Pardis taxation affairs office.

Table 3: frequency of distribution of the Office of Tax Affairs studied in terms of number of delivered declaration forms

\begin{tabular}{|l|l|l}
\hline $\begin{array}{l}\text { Tax } \\
\text { Administration }\end{array}$ & $\begin{array}{l}\text { Number of delivered declaration forms } \\
\left(\mathrm{X}_{3}\right)\end{array}$ & Percent \\
\hline pardis & 1053 & 3.9 \\
\hline
\end{tabular}




\begin{tabular}{|l|l|l}
\hline Boomehen & 10647 & 39.7 \\
\hline Roodehen & 2187 & 8.2 \\
\hline Damavand & 4439 & 16.6 \\
\hline Firoozkooh & 2136 & 8 \\
\hline $\begin{array}{l}\text { Value Added in } \\
\text { the east of } \\
\text { Tehran }\end{array}$ & 6339 & 23.6 \\
\hline total & 26801 & 100 \\
\hline
\end{tabular}

_The number of the tax inclusive files $\left(\mathrm{x}_{4}\right)$ :

The number of the tax inclusive files is a positive $(+)$ indicator.

According to the results of the table number 4, the most plenitude is for Bumehen taxation affairs office and the least plenitude is for Pardis taxation affairs office.

Table 4: Frequency distribution of the Office of State Tax assessed based on the number of the taxable cases

\begin{tabular}{|l|l|l}
\hline $\begin{array}{l}\text { Tax } \\
\text { Administration }\end{array}$ & number of the tax inclusive files (X4) & Percent \\
\hline pardis & 1102 & 4.5 \\
\hline Boomehen & 11134 & 45 \\
\hline Roodehen & 2426 & 10 \\
\hline Damavand & 5076 & 20.5 \\
\hline Firoozkooh & 2801 & 11.3 \\
\hline $\begin{array}{l}\text { Value Added in } \\
\text { the east of } \\
\text { Tehran }\end{array}$ & 2156 & 8.7 \\
\hline total & 24695 & 100 \\
\hline
\end{tabular}

- The ratio of taxation files to the number of taxation workers $\left(\mathrm{x}_{5}\right)$ :

The ratio of taxation files to the number of taxation workers is a negative (-) indicator. according to the results of the table number 5, the most plenitude is for Bumehen taxation affairs office and the least plenitude is for Roodehen taxation affairs office.

Table 5: Frequency distribution of the Office of Tax Affairs in the study, according to the tax records, to the number of tax staff

\begin{tabular}{|l|l|l}
\hline $\begin{array}{l}\text { Tax } \\
\text { Administration }\end{array}$ & $\begin{array}{l}\text { ratio of taxation files to the number of } \\
\text { taxation workers }\left(\mathrm{X}_{5}\right)\end{array}$ & Percent \\
\hline pardis & 115 & 10.8 \\
\hline Boomehen & 253.5 & 23.9 \\
\hline Roodehen & 109.131 & 10.3 \\
\hline Damavand & 238.045 & 22.4 \\
\hline Firoozkooh & 174.179 & 16.5 \\
\hline $\begin{array}{l}\text { Value Added in } \\
\text { the east of } \\
\text { Tehran }\end{array}$ & 171.145 & 16.1 \\
\hline
\end{tabular}




\begin{tabular}{|l|l|l}
\hline total & 1061 & 100 \\
\hline
\end{tabular}

- The number of sent files to the taxation problem solving groups $\left(\mathrm{x}_{6}\right)$ :

The number of sent files to the taxation problem solving groups is a negative (-) indicator. According to the results of the table number 6 , the most plenitude is for Bumehen taxation affairs office and the least plenitude is for Pardis taxation affairs office.

Table 6: Frequency distribution of the tax administrations of the study in terms of the number of cases submitted to the Board of Tax Dispute Resolution

\begin{tabular}{|l|l|l}
\hline $\begin{array}{l}\text { Tax } \\
\text { Administration }\end{array}$ & $\begin{array}{l}\text { number of sent files to the taxation } \\
\text { problem solving groups }\left(\mathrm{X}_{6}\right)\end{array}$ & Percent \\
\hline pardis & 63 & 4.2 \\
\hline Boomehen & 509 & 34.2 \\
\hline Roodehen & 192 & 13 \\
\hline Damavand & 382 & 25.7 \\
\hline Firoozkooh & 127 & 8.5 \\
\hline $\begin{array}{l}\text { Value Added in } \\
\text { the east of } \\
\text { Tehran }\end{array}$ & 214 & 14.4 \\
\hline total & 1487 & 100 \\
\hline
\end{tabular}

B: stages of performing Tapsis method:

Tapsis method constitutes from below stages:

Step Zero: calculating determiner matrix:

In this method a kind of determination is assessed that includes the $\mathrm{m}$ choose and $\mathrm{n}$ indicator.

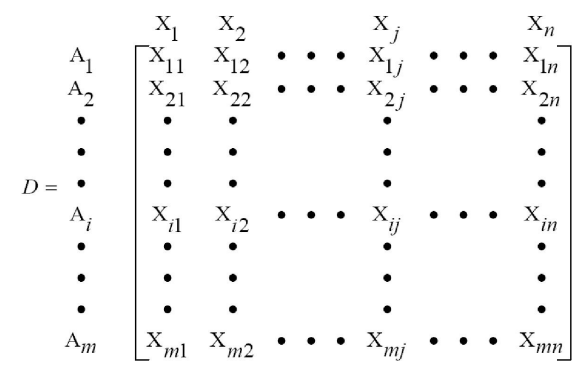

$\mathrm{x}_{\mathrm{j}}$ is the indicator of $\mathrm{j}$

$\mathrm{x}_{\mathrm{ij}}$ is the amount of calculated number from $\mathrm{i}$ choose and $\mathrm{j}$ indicator.

Non-scaling the determiner matrix step: this process omits the scales of the available scales in determiner matrix with the following equation.

First step: omit the scales of the determiner matrix 
This process omits the scale of the available scales in determiner matrix with the following equation.

$$
r_{i j}=\frac{\mathrm{x}_{i j}}{\sqrt{\sum_{i=1}^{m} \mathrm{X}_{i j}{ }^{2}}} \quad \begin{aligned}
& \mathrm{i}=1,2,3, \ldots, \mathrm{m} \\
& \mathrm{j}=1,2,3, \ldots, \mathrm{n}
\end{aligned}
$$

Second step: giving weight to the normalized matrix (calculation of lilting without scale matrix) a collection of weights that $\sum \mathrm{w}_{\mathrm{j}}=1$ by using Shanon Antropy method or by DM for indicators is considered. And with multiplying $\mathrm{j}$ line of $\mathrm{R}$ matrix to related $\mathrm{W}_{\mathrm{j}}$ weight, the weightful normalized determiner matrix is calculated. in this research, the weight of indicators is determined by Shanon Antropi Method.

$v_{i j}=w_{j} \times r_{i j}, \quad j=1,2, \ldots, n ; i=1,2, \ldots, m$,

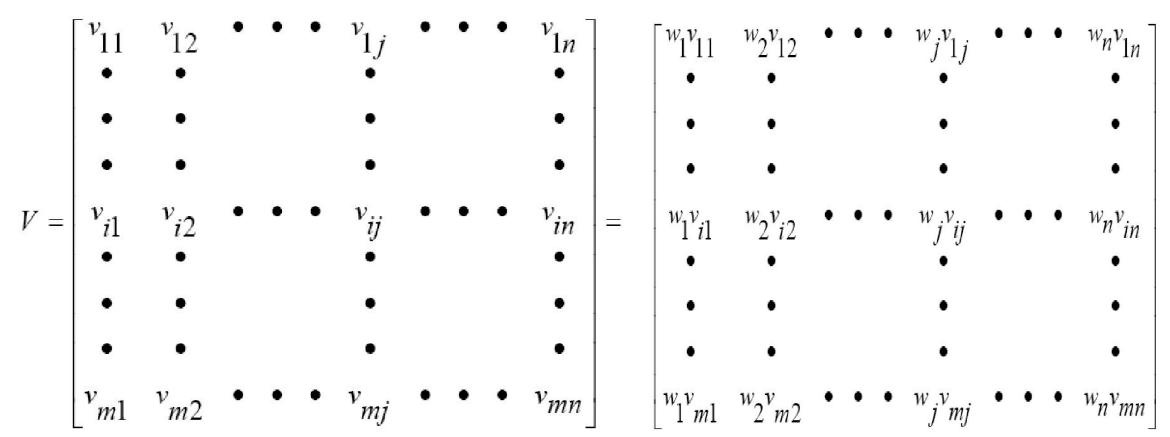

Third step: determining the ideal positive and negative Solution we define two figurative selections $\left(\mathrm{A}^{*}\right.$ the positive ideal selection) and (A the negative ideal selection), as below:

Two calculated figurative selections of $\mathrm{A}^{*}$ and $\mathrm{A}^{-}$are accordingly the best and the worst solutions.

Positive ideal choice $\mathrm{A}^{*}=\left\{\left(\max _{i} v_{i j} \mid j \in J\right),\left(\underset{i}{\min v_{i j} \mid j \in J^{\prime}}\right) \mid i=1,2, \ldots ., m\right\}=\left\{v_{1}^{*}, V_{2}^{*}, \cdots, g V_{j}^{*}, \cdots, g V_{n}^{*}\right\}$ Negative ideal choice $\mathrm{A}^{-}=\left\{\left(\min _{i} v_{i j} \mid j \in J\right),\left(\max _{i} v_{i j} \mid j \in J^{\prime}\right) i=1,2, \ldots . ., m\right\}=\left\{v_{1}^{-}, V_{2}^{-}, \ldots, g \bar{j}^{-}, \ldots g V_{n}-\right\}$

$$
\begin{array}{cl}
\text { Related to Profit index } & j \mapsto J=\{j=1,2,3, \cdots, n\} \\
\text { Related to cost index } & j \mapsto J^{\prime}=\{j=1,2,3, \cdots, n\}
\end{array}
$$

Fourth step: calculation of destination rate: 
We can calculate the distance between selections by measuring the oghlidos distance in $\mathrm{n}$ dimensions space:

The distance of $\mathrm{i}$ choose is calculated from the following formula:

$$
S_{i *}=\sqrt{\sum_{j=1}^{n}\left(v_{i j}-v_{j}^{*)^{2}}\right.} \quad i=1,2,3, \cdots, m
$$

The distance of I choose from negative ideal solution is calculated from following formula.

$$
S_{i-}=\sqrt{\sum_{j=1}^{n}\left(v_{i j}-v_{j}^{-}\right)^{2}} \quad i=1,2,3, \cdots, m
$$

Fifth step: the calculation of partial closeness to the positive ideal solution.

This criterion is calculated from the following formula.

$$
i=1,2, \ldots, m \quad, 0<C_{i}^{*}<1 \quad C_{i}^{*}=\frac{S_{i}^{*}}{S_{i}^{*}+S_{i}^{-}}
$$

Sixth step: rating of chooses:

According to the ascending order of the $\mathrm{C}_{\mathrm{i}}{ }^{*}$, the rating of the taxation affairs office in east of Tehran estate was done according to the effective indicators on taxation capacity. The calculated results of the ratings of the taxation affairs office in east of Tehran is presented in table number 4-14 by Tapsis method.

Table 7: ratings of the Tax Office, of the East of Tehran, based on tax capacity-TOPSIS Method

\begin{tabular}{|l|l|l|l|l}
\hline $\begin{array}{l}\text { East Tax Office in } \\
\text { Tehran }\end{array}$ & Rating & $\mathrm{C}_{\mathrm{i}}^{*}$ & A- & A* \\
\hline Pardis Tax Affairs & 6 & 0.2493 & 0.1 & 0.3011 \\
\hline Boomehen Tax affairs & 1 & 0.7099 & 0.2748 & 0.1123 \\
\hline Roodehen Tax affairs & 5 & 0.2561 & 0.0878 & 0.3049 \\
\hline Damavand Tax affairs & 3 & 0.3231 & 0.1038 & 0.2175 \\
\hline $\begin{array}{l}\text { Firoozkooh Tax } \\
\text { affairs }\end{array}$ & 4 & 0.2812 & 0.0988 & 0.2526 \\
\hline $\begin{array}{l}\text { East of Tehran Value } \\
\text { Added tax affairs }\end{array}$ & 2 & 0.5209 & 0.2053 & 0.1888 \\
\hline
\end{tabular}

The results of the Tapsis method shows that among taxation affairs office in east ofTehran, the Bumehen taxation affairs offices (with $\mathrm{C}_{\mathrm{i}}{ }^{*}=0.7099$ ) has the first rate and the Pardis taxation affairs offices (with a $\left.\mathrm{C}_{\mathrm{i}}^{*}=0.2493\right)$ has the 6 th rate.

\section{RESEARCH RESULTS}

the research results according to the effective indicators on taxation capacity: the derived results of Entropy techniques (for calculating the weight of the indicators) shows that the importance of indicators according to the calculated weights accordingly are: the recovered taxes rate, thr number of inclusive 
files, the number of delivered declaration forms, the number of sent files to the taxation problem solving groups, the number of workers and the ratio of the number of files to the number of workers. We should pay attention that according to the differences of chooses from each indicators aspect, if chooses from indicator's aspect doesn't have much difference or sparseness, so the importance of that indicator is lower than the indicators which chooses from that aspect are more different or have more sparseness. or in other words we can say that the lower weight (the least $\mathrm{W}_{\mathrm{j}}$ with the most $\mathrm{E}_{\mathrm{j}}$ ) shows that the influence of indicator will be same for all of the selections and it's importance in decision making for selecting the choose is so low.

\section{THE RESULTS OF RESEARCH ACCORDING TO DISTANCE AMOUNTS (S ${ }_{\mathrm{A}}^{-}$AND $\left.\mathrm{S}_{\mathrm{A}}{ }^{*}\right)$}

With attention to the calculation of positive ideal distance amount $\left(\mathrm{S}_{\mathrm{A}}{ }^{*}\right)$, the choose of Bumehen taxation affairs office $\left(\mathrm{A}_{2}\right)$ has the lowest distance \& the Pardis taxation affairs office $\left(\mathrm{A}_{1}\right)$ has the most distance with positive ideal. with attention to the calculation of amounts of negative ideal amount $\left(\mathrm{S}_{\mathrm{A}}{ }^{-}\right)$its determined that the selection of Bumehen taxation affairs office $\left(\mathrm{A}_{2}\right)$ has the most distance and the selection of Roodehen taxation affairs office $\left(A_{3}\right)$ has the lowest distance with the negative ideal. Eventually, the rating of the taxation affairs offices in east of Tehran with paying attention to the effective indicators on actual taxation capacity and on the basis of tapsis method, includes accordingly as: Bumehentaxation affairs offices, taxation affairs of added value in east of Tehran, the taxation affairs office in Damavand, the taxation affairs office in Firoozkooh, taxation affairs office in Roodehen and taxation affairs office In Pardis.

\section{REFERENCES}

Abbasi, Ebrahim and Mousavi, Mir Hosein (2009), "Estimating the province's tax capacity", Economic Journal, 13 (48): 164-147.

Alfirman, luky (2003), "Estimating stochastic frontier tax potential: Can Indonesian local governments increase tax revenues under decentralization?", Working Paper 03/19, November.

Alfirman, Luky. "Estimate of stochastic Frontier Tax Potential: Can Indonesian Local Governments Increase Tax Revenues under Decentralization?".Working Paper, No:02-19, (2003).

Amini, A., et al (2008). "Qazvin tax revenue forecasting using time series models and methods of intervention during 1995- 2004", Journal of Economic Policy, Vol XVI, No. 47.

Arab Mazar, A., Pilgrim, Grand (1387). "Assessment of economic potential tax", Proceedings of the conference on financial and tax policies in Iran.

Arabmazar, Ali Akbar and Dehghani, Ali (2008), "Estimating the efficiency of business income tax and legal persons in the provinces", Quarterly Journal of Taxation, New Course, No. VII, 64-45.

Arberry A. J. (1957). "Legacyof Iran" Translation Ahmad Birashk, Translation and Publication Board.

Asghar Pour, J. (1998). Multi-criteria decision making, Tehran, Tehran University Publications.

Azimi, H. (1992), The Economics of Underdevelopment circuits, this publication.

Botlhole, T.d. (2010), "Tax Effort and Determinants of Tax Ratio in Sub-Sahara Africa." International

Conference on Applied Economics, PP. 101-113.

Chelliah, Raja J. (1971), "Trends in taxation in developing countries". Staff Papers, International Monetary Fund, Vol. 18. July.

Chelliah, Raja J.; Baas, Hessel J.; and Margaret, R. Kelly. (1975), "Tax ratios and tax effort in developing countries, 1969-71".IMF Staff Papers, Vol. 22, No. 1, March.

Direct Taxation Act, the Ministry of Economy and Finance

Ehtesham, Morteza (1976), "Iranian Achaemenid era", Joint Publishing Company, pocket books, pages 101-111.

Eltony, M. Nagy. "Measuring Tax Efforts in Arab Countries"., Working Paper, No. 215, (2001).

Eltony, M. Nagy. "The Measuring of Tax Efforts in Arab Countries, Arab Planning Institute"., (2002).

Falihi, N. (2006). "The estimated potential tax effort in Iran". Research and Development Tax, the first year, before the first ring. 
Farazmand, Hasan and Baharvand Ahmadi, Esmail (2008), "A Study of Factors Affecting the fiscal capacity of the province", Quarterly Journal of Taxation, the new, third issue, 168-141.

Gezenfon (1963). "Cyrus ", translated by Reza Mashayekhi, Translation and Publication Board.

Ghani, Zartashia (2011), "A Cross Country Analysis of Tax Performance with Special Focus on Pakistan's Tax Effort".Swedish Business School AtÖrebro University.

Ghatmiri, M. (1991). "Influencing factors on tax capacity". Project economics department of Shiraz University.

Ghatmiri, M., Aslamluian, K. (2006). "Calculation of tax effort provinces using numerical taxonomy". Quarterly financial and development, the second number.

Ghatmiri, M., Aslamluian, K. (2006). "Estimated tax capacity and its comparison with selected countries of entrepreneurship research projects.

Ghodsi, Mojtaba (2010). "Evaluation of of Tax capacity and of Tax effort in Iran," MA thesis, Economics, Faculty of Economics, Allameh Tabatabai University.

Hanifi .Farhad, Aligholi. Mansoureh, Asayesh. Kourosh(2014) Investigation and Comparison of Ohlson, Model, Economic Value Added Model and Dividend Discount Model in 50 Top Companies in Tehran StockExchange ,Journal of Applied Environmental and Biological Sciences, 4(9)87-92.

Hawar K. (1996). "Iran and the Iranian civilization 'translation of Anousheh, Kabir publication.

Hudson, J. \& J. Teera. "Tax Performance: A Comparative Study"., Journal of International Development, No. 16, (2004): 785-802.

Indicators of Taxation, State Taxation Affairs Organization, various issues.

Jahangir, M. (2008). 'Direct Taxes Code', the twenty-seventh edition, Didar publication.

Jalaei, Syed Abdolmajid and Ghaseminejad, Amin (2013), "Estimating the actual tax capacity of the particle mass optimization algorithm (PSO) and Genetic Algorithm (GA)", Journal of Taxation, New Course No. Title 9 -29.

Komeijani, A., Fahim, Yahyaei, F. (1991). "Analysis of the composition of taxes and estimated tax capacity." Journal of Economics and Management, Islamic Azad University, Third Year, No. 8, and 9.

Leuthold, Jane H. "Tax Effort in China"., Working Paper, No. 105, (2002).

Malchofski, Yachek (2006). GIS and Multi Criteria Decision Analysis. Translated by A. Ghaffari righteous and blessed. Gylandh, Tehran, and codified books organization studies of Social Sciences (left). Mankiow, Gregory (1995). "Macroeconomics", translated by Hamidreza Ali Parsaeian partners and brothers, Tehran, Allameh Tabatabai University Press.

Manouchehr F. (1984). Dictionary of Economics, The Free Press, 1274, p.

Mehregan, Nader, Pejman, Nader (2005). "Estimation of Tax provinces using data from a combination of" Research and Economic Policy, Vol XIV, No. 35.

Monjazeb, MR, Soleimani, P. (2005). "Estimation of Tax province," Economic Journal, No. XVIII, 162139.

Monjazeb, MR, Soleimani, P. (2005). "Estimation of Tax province," Economic Journal, No. XVIII, 162139.

Mousavi Jahromi, Y., and Zayer, Ayat (2008), "A comparison of multiple criteria decision-making models, case study: Factors influencing the ranking of provinces based on tax capacity", Economic Journal, Economic Supplement Plan Amendment, 44-15.

Mousavi, Seyed Yahya (2008). "of Tax Efficiency and determine the capacity of the county," MA thesis, Economics, School of Economics and Political martyr Beheshti University,

Movahedi, M., Motamedi, M. (2010). Introduction to the theory of decision analysis, Tehran, publication of Moallef.

Naderan, Elyas (2005). "Estimated tax bill due to the implementation of VAT in Iran". Ministry of Finance and Economic Affairs Office of VAT.

Pajooyan, J. (2006). "Investigation of Iranian provincial taxes and provide justification proposals to reform the tax system." Research projects Research Office tax aspects of entrepreneurship.

Parvin, S. "Income distribution and growth". Proceedings of the Symposium on Poverty and Poverty Alleviation Study, Plan and Budget Organization, May (1996). 
Rajab Zadeh, A., Azar, A. (2002). Decision making approach .MADM Tehran, Negah-e- Danesh.

Sameti Mortaza, Sameti, Majid (2000). A method for measured tax capacity of the provinces. Tehran, Department of Economic Affairs, Ministry of Economic Affairs and Finance.

Sami, A. (1964). "Achaemenid civilization" (Volume 2), publications printing Mousavi Shirazi, page 64. Shoderbek, Peter; Shoderbek, Charles and Kafalas, Estrios (2006). Management systems and theoretical studies Z. .trjmh Iran, Tehran, forest.

Value added tax law, enacted in 2008

weekly magazine of program, different numbers.

www.intamedia.ir

www.staff.alzahra.ac.ir/saniee/Hompage

www.tax.blogfa.com 